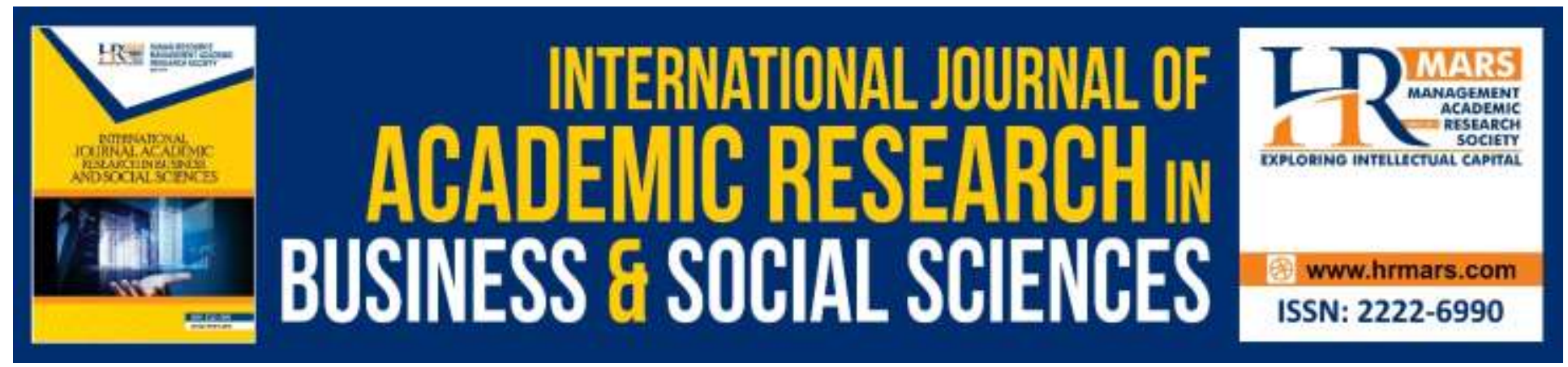

\title{
Technological Development in Developing Countries: A Process of Imitation and R \& D
}

\section{Kamilia Loukil}

To Link this Article: http://dx.doi.org/10.6007/IJARBSS/v9-i11/6560

DOI: $10.6007 /$ IJARBSS/v9-i11/6560

Received: 02 April 2019, Revised: 30 May 2019, Accepted: 09 June 2019

Published Online: 27 November 2019

In-Text Citation:(Loukil, 2019)

To Cite this Article: Loukil, K. (2019). Technological Development in Developing Countries: A Process of Imitation and R \& D. International Journal of Academic Research in Business and Social Sciences, 9(11), 431-436.

Copyright: (C) 2019 The Author(s)

Published by Human Resource Management Academic Research Society (www.hrmars.com)

This article is published under the Creative Commons Attribution (CC BY 4.0) license. Anyone may reproduce, distribute, translate and create derivative works of this article (for both commercial and non-commercial purposes), subject to full attribution to the original publication and authors. The full terms of this license may be seen at: http://creativecommons.org/licences/by/4.0/legalcode

\begin{tabular}{|c|c|}
\hline \multicolumn{2}{|c|}{ Vol. 9, No. 11, 2019, Pg. $431-436$} \\
\hline http://hrmars.com/index.php/pages/detail/IJARBSS & JOURNAL HOMEPAGE \\
\hline
\end{tabular}

Full Terms \& Conditions of access and use can be found at http://hrmars.com/index.php/pages/detail/publication-ethics 


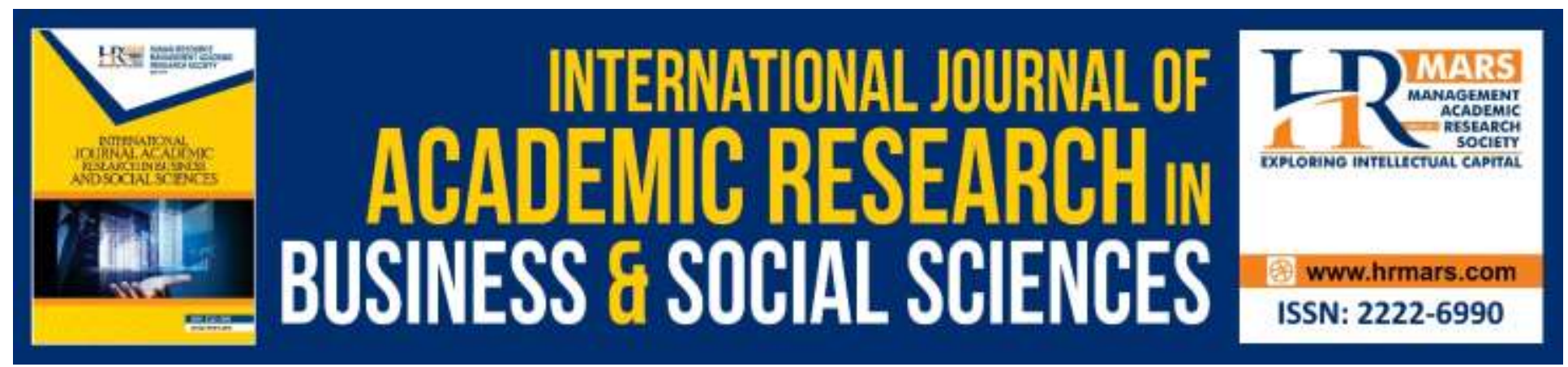

\title{
Technological Development in Developing Countries: A Process of Imitation and R \& D
}

\author{
Kamilia Loukil \\ Department of Economics, Faculty of Economics and Management of Sfax, Airport road km 4, \\ 3018, Sfax - Tunisia \\ Email: kamilia.loukil@gmail.com
}

\begin{abstract}
This paper examines the process of technological development in developing countries. We aim to summarize the steps of innovation in such economies. To that end, we present some theoretical arguments and the practical case of Korea. The paper shows that the imitation of advanced technologies is an important learning process for the catching-up of latecomers, but it is not enough. An active innovation through domestic research and development is crucial for successful technological catch-up.
\end{abstract}

\section{Introduction}

Technological innovation in developing countries aims to achieve a catching up, that is a reduction of technological gap between competitors thanks to rapid technological learning by latecomers. Most young firms are unable to internally generate all the knowledge required to continuous technological development. They often depend on external sources (Song et al, 2003).

In a context of technological catch-up, innovation depends critically on the country's links with the rest of the world. The acquisition of technology in latecomers depends on technology transfer. However, access to foreign technology is not equivalent to its effective use. Although equipment and technology models can be imported from advanced countries, the ability to make effective use of these elements cannot be transferred in the same way. These skills are only acquired through a local learning process. This is because knowledge has tacit elements, and because it is often necessary to adapt foreign technologies to local conditions. The imitation of advanced technologies is an essential learning process for the catching-up of latecomers because the influx of external knowledge at an early stage form the cornerstone of future technological development. Yet, passive imitation of existing knowledge is not enough for a long-term technological catch-up success. In the first phase of catching-up, latecomers generally receive obsolete technologies from leading countries. However, when they reach a certain technological level, most advanced countries are reluctant to transfer new 
technologies. Thus, an active innovation through domestic Research and Development (R\&D) becomes a crucial factor for technological catch-up (Kim, 1980; Lee et al, 1988).

This paper aims to examine the process of technological development in developing countries. The rest of the paper is organized as follows: Section 2 focuses on defining the mechanisms of acquisition of foreign technology. Section 3 introduce imitation as an activity of innovation in developing countries. Section 4 proposes the technological catch-up model relative to Korea claiming that technological catch-up succeeds only through the combination of two types of activities: imitation and R\&D. Section 5 includes some concluding remarks.

\section{Mechanisms of Acquisition of Foreign Technology}

The international transfer or diffusion of technologies refers to the process by which a company in one country accesses and uses technology developed in another country. Some transfers occur between partners in the context of voluntary transactions, they are formal channels of technology transfer. Others take place through non-market transactions. They are informal channels.

Formal channels include:

$>$ International trade: Which can contribute to technology transfer by allowing local companies reverse engineering and access to new machinery and equipment. Coe and Helpman (1995) find that foreign R\&D embodied in traded goods has a significantly positive impact on the total factor productivity of importing countries. Exports are also likely to be an important channel for diffusion of technology. Grossman and Helpman (1991), for example, argue that sellers benefit from the knowledge base of their buyers when they suggest ways to improve the product or production process.

$>$ Foreign direct investment (FDI): Multinational companies allow their subsidiaries access to advanced technologies that can be disseminated to companies in the host country. FDI can provide developing countries with more efficient technologies, resulting in technological spillovers and increased competition. Case studies suggest that a considerable diffusion of technology is due to FDI (Blomstrom and Kokko, 1998).

$>$ Joint ventures, which are a form of FDI, also allow for the transfer of technology.

$>$ Licensing contracts that involve the purchase of rights to produce and distribute a product and the necessary knowledge to make effective use of these rights.

$>$ The international circulation of persons: This is the case when nationals study or work abroad for a limited period of time and apply their new knowledge when they return. This is also the case for the movement of foreign nationals in the country.

Informal channels for disseminating technology include, for example the movement of staff from one company to another, bringing with them specific knowledge about the technologies of their original company, and the data recorded in the patent applications.

\section{The Imitation: An Innovation Activity in Developing Countries}

In public opinion, imitation refers to the illegal copying of original products. It is often considered a criminal activity and leaves out of sight a whole range of different types of imitation practices. Yet the content of these imitative practices indicates the existence of a direct potential of knowledge production. 
There are several typologies of imitation.

Lee and Zhou (2012) distinguish between pure imitation and creative imitation.

Pure imitation: Takes place when the company clones its products to be identical to those of the competitors.

Creative imitation: Takes place when the company modifies or adds new characteristics or functions to its own products based on the products of its competitors.

Similarly, Kim (2001) distinguishes between duplicative imitation and creative imitation. He stresses the importance of reverse engineering, which refers to the duplicative imitation of mature foreign products. According to Eilam (2005, p. 3), reverse engineering can be defined as "The process of extracting the knowledge or design of blueprints from anything man-made". It generally aims to understand the structure and operation of an object in order to make a new device or program. Thus, a similar object is created in a different way by copying or improving it.

Schnaars (1994) distinguishes between four types of imitation.

$>$ Counterfeits: are illegal duplications bearing the same brand name as the original product;

$>$ Imitations: are legal copies similar to original products bearing their own brand names and developed due to the absence or expiry of the legal protection of competing products;

$>$ Design Copies: are copies of style, design of the competitor's product bearing its own brand name and having its own unique technical specifications. They can be based on a unique and innovative technology;

$>$ Creative adaptations: are creative improvements to the competitor's products, adaptations of existing ideas to new applications as well as truly innovative solutions inspired by the competitor's supply.

Imitation has several advantages. Indeed, knowledge transferred is beneficial for rapid catch-up because it can be easily absorbed and understood by beneficiaries (Zander and Kogut, 1995). Existing technology is also sound of technological uncertainty as it has already gone through evaluation and verification by competitors and the market. Thus, imitation can reduce the risk of failure of technological invention, avoid waste of company resources and facilitate the catch up of the leader's technological expertise. In other words, late firms can improve their likelihood of short-term survival through learning and imitation of leaders. The long-term goal of imitation is to build a learning ground on which the ability to innovate can be further developed.

\section{The Process of Technological Development: Case of Korea}

Kim (1980) points out that the development of industrial electronics technology in Korea has gone through three stages: implementation, assimilation and improvement.

The electronics industry in Korea was originally created in response to a market opportunity created and protected by public import substitution policy. In most cases, product design and production technologies were imported from abroad. Production at this stage was merely an assembly operation of parts and components of foreign origin, and the technological concern of the company was essentially the implementation of the production process. Little efforts have 
been made to introduce technological changes to products and processes due to lack of technological capabilities and incentives to make these changes.

As product design and production techniques transferred from abroad were successfully implemented in a number of companies, technical know-how spread rapidly throughout the country, resulting in an increase of the number of competing firms in the same market. The accumulated experience in design and production has provided a basis for indigenous efforts to assimilate foreign technologies.

Finally, assimilation of foreign technology and increased competition in the market combined with increased local capacity of scientific and engineering personnel lead to the gradual improvement of foreign technology. Product improvement and cost reduction become an important basis for competition not only in the domestic market, but also in international markets that have become increasingly important. Indigenous efforts in favor of technological change have become important to improve products and increase productivity, leading to a relatively more efficient, integrated and larger production system.

\section{Conclusion}

The objective of this paper was to describe the technological development process in developing countries. According to theoretical arguments and the case study of Korea, we conclude that the process of technological development depends heavily on technologies developed in advanced countries. The imitation of these technologies is a necessary step towards development, but it is not enough. Technological catch-up only succeeds thanks to domestic R\&D activities.

\section{References}

1. Blomstrom, M., Kokko, A. (1998). Multinational corporations and spillovers. Journal of Economic Surveys 12 (2).

2. Coe, D. T., Helpman, E. (1995). International R\&D spillovers.European Economic Review 39: 859-887.

3. Eilam, E. (2005). Foundations. In Reversing: Secrets of reverse engineering, Wiley Publishing, Inc.

4. Grossman, G. M., Helpman, E. (1991). Quality ladders in the theory of growth.Review of Economic Studies 58: 86-91.

5. Kim, L. (1980). Stages of development of industrial technology in a developing country: A model. Research Policy 9: 254-277.

6. Kim, L. (2001). The dynamics of technological learning in industrialisation. International Social Science Journal 53 (168): 297-308.

7. Lee, J., Bae, Z. T., Choi, D. K. (1988). Technology development processes: A model for a developing country with a global perspective. R\&D Management 18 (3): 235-250.

8. Lee, R. P., Zhou, K. Z. (2012). Is product imitation good for firm performance? An examination of product imitation types and contingency factors. Journal of International Marketing 20 (3): 1-16.

9. Schnaars, S. P. (1994). Managing imitation strategies, New York: The Free Press. 
10. Song, J., Almeida, P., Wu, G. (2003). Learning by hiring: When is mobility more likely to facilitate inter firm knowledge transfer? Management Science 49(4):351-365.

11. Song, J., Almeida, P., Wu, G. (2003). Mobility of engineers and international knowledge transfer: Technological catching-up in the Korean and Taiwanese semiconductor industries. APEC Study Center Columbia Business School Discussion Paper: 19.

12. Zander, U., Kogut, B. (1995). Knowledge and the speed of the transfer and imitation of organizational capabilities: An empirical test. Organization Science, 6: 76-92. 